\title{
DEVELOPMENT AND VALIDATION OF A SPE-UHPLC-FLUORESCENCE METHOD FOR THE ANALYSIS OF OCHRATOXIN-A IN CERTAIN TURKISH WINES
}

\author{
Elif Mine Öncü-Kaya \\ Eskisehir Technical University, Science Faculty, Department of Chemistry, 26470, Eskisehir, Turkey \\ emoncu@eskisehir.edu.tr
}

A sensitive Ultra-High Performance Liquid Chromatography (UHPLC)-fluorescence method was developed and validated for the determination of ochratoxin-A (OTA) in Turkish wine samples. Naphthalene was used as an internal standard in this study. OTA was separated on a C18 $(3.0 \mathrm{~mm} \times 100 \mathrm{~mm} \times 1.8$ $\mu \mathrm{m})$ column and analyses were run under isocratic conditions, with a mobile phase consisting of water/acetonitrile/acetic acid (50:50:1, v/v/v). The flow rate and injection volume were $0.5 \mathrm{ml} \mathrm{min}^{-1}$ and 10 $\mu \mathrm{l}$, respectively. The excitation and emission wavelengths were $330 \mathrm{~nm}$ and $460 \mathrm{~nm}$ for OTA, respectively, and $220 \mathrm{~nm}$ and $325 \mathrm{~nm}$ for internal standard, respectively. A solid-phase extraction (SPE) clean-up procedure on a $\mathrm{C} 18$ cartridge was used prior to the analysis of the wine samples by UHPLC. The developed method was validated with respect to linearity, precision, accuracy, limit of detection (LOD), limit of quantitation (LOQ), stability and robustness. The method presented good RSD $(<4 \%)$ and recovery (102.6-105.2\%) values. The LOD and LOQ values were $0.01 \mathrm{ng} \mathrm{ml}^{-1}$ and $0.05 \mathrm{ng} \mathrm{ml}^{-1}$, respectively. All other parameters were acceptable. OTA amounts were found in the range of $2.72-7.40 \mu \mathrm{g} \mathrm{kg}^{-1}$ in the Turkish wine samples.

Keywords: UHPLC-FLD; ochratoxin A; Turkish wine; validation; SPE

\section{РАЗРАБОТКА И ВАЛИДАЦИЈА НА SPE-UHРLС-ФЛУОРЕСЦЕНТЕН МЕТОД ЗА АНАЛИЗА НА ОХРАТОКСИН-А ВО НЕКОИ ТУРСКИ ВИНА}

Разработен е и валидиран осетлив ултрависокоефикасен течен хроматографиски (UHPLC) флуоресцентен метод за определување на охратоксин-А (ОТА) во примероци на турски вина. Како внатрешен стандард во ова истражување беше употребен нафтелен. Раздвојувањето на ОТА беше извршено на колона С18 $(3.0 \mathrm{~mm} \times 100 \mathrm{~mm} \times 1.8 \mu \mathrm{m})$, а анализите беа извршени во изократски услови, каде мобилна фаза се состоеше од вода/ацетонитрил/оцетна киселина (50:50:1, v/v/v). Протокот и инјектираниот волумен соодветно изнесуваa $0,5 \mathrm{ml} \mathrm{min}{ }^{-1}$ и $10 \mu \mathrm{l}$. Брановите должини за екцитација и емисија изнесуваа соодветно $330 \mathrm{~nm}$ и $460 \mathrm{~nm}$ за ОТА, односно, соодветно $220 \mathrm{~nm}$ и $325 \mathrm{~nm}$ за интерниот стандард. Пречистувањето беше извршено со цврсто-фазна - SPE постапка на C18 картриџ пред да се изврши анализата на примероците вино со UHPLC. Разработениот метод беше валидиран во однос на линеарноста, прецизноста, точноста, прагот на детекција (LOD), прагот на квантификација (LOQ), стабилноста и робустноста. Методот покажа добри вредности за релативната стандардна девијација - RSD $(<4 \%)$ и аналитичкиот принос $(102,6-$ $105,2 \%$ ). Вредностите за LOD и LOQ соодветно изнесуваа $0,01 \mathrm{ng} \mathrm{ml}^{-1}$ и $0,05 \mathrm{ng} \mathrm{ml}^{-1}$. Сите останати параметри бе задоволувачки. Количеството на ОТА во примероците на турските вина изнесуваа во опсегот од $2,72-7,40 \mu \mathrm{g} \mathrm{kg}^{-1}$.

Клучни зборови: UHPLC-FLD; охратоксин-А; турски вина; валидација; SPE 


\section{INTRODUCTION}

Mycotoxins are toxic secondary fungous metabolites that have negative effects on humans, plants, animals, and microorganisms. OchratoxinA (OTA), the most commonly encountered mycotoxin in food samples, is generated by various genera of Aspergillus and Penicillium and may exist naturally in several foods, including coffee, cocoa, spices, dried fruits, cereals, cereal products, beans, groundnuts, milk, meat, beer, grape juice and wine. OTA possesses immunotoxic, nephrotoxic, embryotoxic, teratogenic, hepatotoxic, genotoxic, neurotoxic, and carcinogenic effects. Moreover, OTA has a long half-life (about 35 days) in human serum, meaning that it cannot be eliminated quickly from the plasma [1-5]. All of these factors make OTA among the most interesting of mycotoxins.

Humans have been exposed to OTA from an extensive range of foods which show low levels of contamination [6]. Wine is considered one of the most common sources of OTA contamination, especially in European countries, after cereals [7]. Grapes are the origin of OTA contamination in wines, because deteriorated grapes can be readily infected by fungi and generate OTA [3]. The Joint Food and Agriculture Organization of the United Nations (FAO)/World Health Organization (WHO) Expert Committee on Food Additives (JECFA) proposed that the tolerable weekly intake of OTA should be $100 \mathrm{ng} \mathrm{kg}^{-1}$ of body weight (b.w.) [8]. The tolerable daily intake of OTA should be less than $5 \mathrm{ng} \mathrm{kg}^{-1}$ of b.w. according to the Scientific Committee for Food (SCF) [9]. European Commission Regulation EC 1881/2006 [10] set the maximum level of OTA to $2.0 \mu \mathrm{g} \mathrm{kg}^{-1}$ for wines (red, rosé and white). Because of the toxicity of OTA, even in very small amounts, highly selective and sensitive analytical methods are required for the analysis of OTA in food samples [11]. With regard to food, however, there is always a need for the development of new and reliable analytical methods. OTA can be determined in various foods using an array of analytical methods. These include enzyme-linked immunosorbent assay (ELISA) [12, 13], thin layer chromatography (TLC) [14], gas chromatography-mass spectrometry (GC-MS) [15, 16], high performance liquid chromatography (HPLC) $[17,18]$ and ultra-high performance liquid chromatography (UHPLC) with fluorescence detection (FLD) [19] or mass spectrometry (MS) [20]. Of these methods, HPLC and UHPLC are commonly utilized for the analysis of OTA because of their high separation efficiency and the low limits of quantification of used detectors. In recent years, UHPLC has replaced HPLC due to its improved instrumentation and column technologies. UHPLC provides high resolution separation, more sensitive analysis and rapid method development due to its lower analysis time and faster column equilibration. Advanced UHPLC detectors are favored for obtaining small peak widths without significant band broadening and also the improved signal-to-noise ratios of detectors allow the detection of analytes at extremely low concentrations. In addition, UHPLC columns packed with sub- $2 \mu \mathrm{m}$ particles exhibit enhanced separation efficiency compared to conventional HPLC columns $[11,21-23]$.

The aim of this study was to develop and validate a new and a sensitive UHPLC-FLD method using an internal standard (IS) for the analysis of OTA in Turkish wines. Numerous studies using liquid chromatographic methods, including HPLC and UHPLC with fluorescence (FLD) [24-26] and mass spectrometry (MS) detectors [27, 28], have reported the presence of OTA in wines originating from various regions. However, there have been few HPLC studies regarding Turkish wines using conventional HPLC columns. Anli et al. [29] studied the OTA contents in 47 wines from different regions in Turkey using the HPLC-FLD method. They separated OTA in approximately 25 minutes on an SGE Wakosil C18 HPLC column $(4.6 \mathrm{~mm} \times$ $250 \mathrm{~mm} \times 5 \mu \mathrm{m})$. They used an extraction method following a Sep-pack cartridge for preparation of the wine samples. However, their sample preparation method was laborious and the HPLC method validation was not exhaustive. Moreover, they did not use an IS during the research. Var and Kabak [7] also studied OTA in different Turkish wines. They separated OTA in 13 minutes using an ACE C18 column $(4.6 \mathrm{~mm} \times 250 \mathrm{~mm} \times 5 \mu \mathrm{m})$ and they also did not utilize an IS. They used an immunoaffinity column (IAC) to clean-up Turkish wines. Altiokka et al. [30] determined the OTA levels in 25 different Turkish wines by HPLC-FLD with a reversed phase Nucleosil C18 column (4.6 $\mathrm{mm} \times 150 \mathrm{~mm} \times 3 \mu \mathrm{m})$. They used diflunisal as an IS and both OTA and IS were separated within 13 minutes. They did not use any extraction or concentration steps for their wine samples and injected the samples directly into the chromatographic system. To the best of my knowledge, there have been no studies of Turkish wines using a UHPLC-FLD method with newly generated small particle UHPLC columns. As a result, it is believed that this study will contribute to the literature associated with OTA determination in Turkish wines. In summary, when the related studies are examined in 
the literature, the described method has some advantages such as shorter analysis time, lower costs due to the consumption of less solvent in UHPLC, better performance characteristics and the use of an IS. In addition, a full method validation was performed in this study.

\section{EXPERIMENTAL}

\subsection{Chemicals and materials}

The analytical standards of OTA and naphthalene (IS), methanol ( $\geq 99.9 \%)$ and acetonitrile ( $\geq 99.9 \%$ ) were obtained from Sigma-Aldrich (St. Louis, MO, USA). Glacial acetic acid (99.5\%) was provided by Carlo Erba (Milan, Italy). Solid phase extraction (SPE) was performed using a Supelclean $500 \mathrm{mg}$ C18 SPE cartridge (Supelco, Beilefonte, PA, USA). The Sartorius water purification system (Rotterdam, Netherland) was used to obtain ultra-pure water. A Sonorex ultrasonic bath (Bandelin, Berlin, Germany) was utilized for the degassing of solutions. A Vortex (2G 560-E, Daigger Scientific Industries, Bohemia, USA) was utilized for the mixing process. All of the standard and sample solutions were filtered from $0.2 \mu \mathrm{m}$ particle size with $25 \mathrm{~mm}$ diameter disposable cellulose acetate syringe filters (Sartorius, Germany) before the UHPLC injections.

\subsection{Wine samples}

The samples are commercial wines and all the wines used in the experiments were of good quality. Red, rosé and white wine samples were bought from several local markets in Eskisehir (Turkey). In this study, different Turkish wine brands were used from various regions of Turkey; the properties of wine samples are given in Table 1.

Table 1

The properties of commercial Turkish wine samples used in this study

\begin{tabular}{|c|c|c|c|c|c|}
\hline $\begin{array}{l}\text { Sample } \\
\text { No }\end{array}$ & Color & $\begin{array}{l}\text { Alcohol } \\
\text { content } \\
(\mathrm{v} / \mathrm{v} \%)\end{array}$ & $\begin{array}{c}\text { Production } \\
\text { year }\end{array}$ & Region & Grape varieties \\
\hline 1 & Red & 12 & 2014 & Aegean & Bogazkere\&Carignan \\
\hline 2 & White & 12 & 2014 & Thrace & Sauvignon Blanc\&Chardonnay \\
\hline 3 & Red & 14.5 & 2013 & Denizli-Aegean & $\begin{array}{l}\text { Shiraz\&Merlot\&Kalecik Karası\&Cabernet } \\
\text { Sauvignon }\end{array}$ \\
\hline 4 & White & 11.5 & 2014 & $\begin{array}{l}\text { Murefte } \\
\text { (Thrace)\&Aegean }\end{array}$ & Sultaniye \&Semillion \\
\hline 5 & White & 12 & 2014 & Cappadocia\&Tokat & Anatolian \\
\hline 6 & White & 11 & 2014 & Aegean & Sultaniye\&Chardonnay \\
\hline 7 & White & 13.5 & 2014 & Denizli-Aegean & Sultaniye \\
\hline 8 & Rosé & 14.5 & 2013 & Thrace\&Aegean & Calkarası\&Cinsault \\
\hline 9 & Red & 13.8 & 2014 & Izmir\&Aegean & $\begin{array}{l}\text { Cabernet Sauvignon\&Alicante\&Merlot\& } \\
\text { Carignan }\end{array}$ \\
\hline 10 & Red & 12.5 & 2014 & Elazıg\&Diyarbakır & Okuzgozu\&Bogazkere \\
\hline 11 & Red & 14.5 & 2013 & East-Anatolia\&Aegean & Okuzgozu\&Shiraz\&Alicante \\
\hline 12 & Red & 13 & 2014 & Tekirdag-Thrace & Shiraz\&Merlot \\
\hline 13 & Red & 15 & 2013 & Denizli-Aegean & Bogazkere\&Shiraz \\
\hline 14 & Red & 13.5 & 2014 & Elazıg\&Diyarbakır\&Izmir & Okuzgozu\&Bogazkere\&Alicante\&Carignan \\
\hline 15 & Red & 14.5 & 2013 & Thrace\&Aegean & Cinsault\&Alicante\&Bogazkere \\
\hline
\end{tabular}

\subsection{Instrumentation and UHPLC-FLD Conditions}

The analyses were conducted with an Agilent 1290 Infinity UHPLC instrument (Waldbronn, Germany) using a fluorescence detector (FLD). OTA was separated on a C18 Zorbax Eclipse Plus $(3.0 \mathrm{~mm} \times 100 \mathrm{~mm} \times 1.8 \mu \mathrm{m})$ UHPLC column with a mobile phase system composed of water:acetonitrile:acetic acid (50:50:1, v/v/v) under isocratic conditions. The injection volume and flow

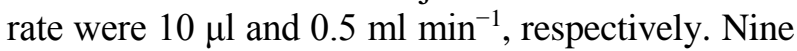
$\mu \mathrm{l}$ of OTA standard or wine sample and $1 \mu \mathrm{l}$ of IS $\left(1.82 \times 10^{-6} \mathrm{M}\right)$ were mixed by the auto sampler. During the analyses, the UHPLC column and auto sampler were kept at $25^{\circ} \mathrm{C}$ and $10{ }^{\circ} \mathrm{C}$, respectively. The excitation and emission wavelengths were 330 and $460 \mathrm{~nm}$ for OTA, and 220 and $325 \mathrm{~nm}$ for IS, respectively. 


\subsection{Preparation of solutions}

One mg of OTA was dissolved in $1 \mathrm{ml}$ of methanol and stored at $-20{ }^{\circ} \mathrm{C}$. A working solution of OTA (1000 ng ml $\mathrm{m}^{-1}$ ) was prepared in methanol/water $(50: 50, \mathrm{v} / \mathrm{v})$ and further OTA standard solutions $(0.36,3.60,9.00,18.00,45.00,180 \mathrm{ng}$ $\mathrm{ml}^{-1}$ ) were prepared from this solution. For the preparation of a stock naphthalene (IS) solution, $15.5 \mathrm{mg}$ of naphthalene was weighed and dissolved in $10 \mathrm{ml}$ of methanol. Following this, in order to prepare a working solution of $1.82 \times 10^{-6} \mathrm{M}$, the appropriate volume of stock IS solution was diluted with methanol/water $(50: 50, \mathrm{v} / \mathrm{v})$.

\subsection{Solid phase extraction (SPE) method}

The solid phase extraction (SPE) method was conducted following previous studies by Hernandez et al. [31] and Leitner et al. [28] with slight modifications. A C18 SPE cartridge was preconditioned using $5 \mathrm{ml}$ of methanol and then $5 \mathrm{ml}$ of water without allowing the cartridge to dry. Ten $\mathrm{ml}$ of a wine sample was transferred to the cartridge. Subsequently, the cartridge was washed with $2 \mathrm{ml}$ of water and then dried for approximately $30 \mathrm{sec}-$ onds. OTA was eluted through $2 \mathrm{ml}$ of methanol and the residue was diluted with water. Then, the sample solution was filtered from syringe filter before the UHPLC injection.

\subsection{Validation of the UHPLC-FLD method}

Validation of the UHPLC-FLD method was conducted via precision, linearity, limit of detection (LOD), limit of quantification (LOQ), accuracy, stability and robustness, according to ICH [32]. In order to test the precision of the proposed method, repeatability studies were carried out by means of measuring intra-day and inter-day values for three concentration levels of OTA. Accuracy was tested via recovery percentage by spiking with three concentration levels of standard OTA prior to extraction from rosé wine. The spiked samples were extracted twice and injected in triplicate under the previously established optimum UHPLCFLD conditions. The linearity of the calibration curve was evaluated for six different OTA standard levels in the range of $0.36-180 \mathrm{ng} \mathrm{ml}^{-1}$ under optimum UHPLC-FLD conditions. A fixed concentration of $1.82 \times 10^{-7} \mathrm{M}$ IS was used in all the experiments. The stability of OTA was evaluated using three different concentrations under various conditions, including short-term stability, long-term stability and freeze-thaw stability. The OTA solutions were kept for 24 hours at room temperature in order to test short-term stability. For long-term stability, the OTA solutions were left at $-20{ }^{\circ} \mathrm{C}$ for two weeks. To test the freeze-thaw stability, the OTA solutions were kept at $-20{ }^{\circ} \mathrm{C}$ and then thawed to room temperature three times. The robustness was tested with small variations in the UHPLC-FLD method parameters. In this context, column temperature, flow rate, and the composition of acetonitrile were altered for the robustness study.

In this study, the peak-normalization $(\mathrm{PN})$ method calculating the ratio of peak area (A) values to their retention times (Rt), $\mathrm{PN}=\mathrm{A} / \mathrm{Rt}$, was used. After this, the ratios of PN values for OTA and IS ( $\left.\mathrm{R}=\mathrm{PN}_{\text {отA }} / \mathrm{PN}_{\mathrm{IS}}\right)$ were used. All of the statistical calculations were performed at a $95 \%$ probability level.

\subsection{Statistical analysis}

The Graph Pad Prism v6.0 program and Microsoft Excel programs were utilized to carry out the statistical analyses.

\section{RESULTS AND DISCUSSION}

\subsection{Optimization of the UHPLC-FLD method}

In general, chromatographic separations of OTA in wine have been carried out using conventional HPLC C18 columns and isocratic elution with acidified acetonitrile or methanol and water in the literature. Sodium acetate-acetic acid and an acetonitrile mobile phase systems were also used in some studies [33]. The proposed UHPLC-FLD method was developed according to the methods used for determination of OTA [26, 34], with slight modifications. In this study, a C18 Zorbax Eclipse Plus $(3.0 \mathrm{~mm} \times 100 \mathrm{~mm} \times 1.8 \mu \mathrm{m})$ UHPLC column was utilized during the analyses with similar to Turcotte and Scott [34]. During the analyses, the UHPLC column and auto sampler were kept at 25 ${ }^{\circ} \mathrm{C}$ and $10{ }^{\circ} \mathrm{C}$ different from Gentile et al. [26] and Turcotte and Scott [34]. Various flow rates such as $0.4 \mathrm{ml} \mathrm{min}-1,0.5 \mathrm{ml} \mathrm{min}{ }^{-1}$ and $0.6 \mathrm{ml} \mathrm{min}^{-1}$ were applied in order to achieve the best resolution of OTA from other peaks in wine matrices using the mobile phase system of water:acetonitrile:acetic acid (50:50:1, v/v/v). The optimum flow rate was found to be $0.5 \mathrm{ml} \mathrm{min}{ }^{-1}$. In this study, the mobile phase is also similar to that used by Gentile et al. [26] and Turcotte and Scott [34]. The appropriate injection volume was applied as $10 \mu 1$ when considering the size of the UHPLC column. Different 
chemicals including caffeine, diflunisal, methyl, ethyl, propyl and butyl paraben, were tried as an IS and considering the wine matrices, naphthalene was found to be the most suitable IS for this system. Gentile et al. [26] and Turcotte and Scott [34] did not use an IS, unlike this study.

OTA and IS were detected at retention times of 4.2 and 7.9 minutes, respectively, under the previously mentioned optimum UHPLC-FLD chromatographic conditions ('Section 2.3.'). Typical UHPLC-FLD chromatograms of OTA standard (45.0 $\mathrm{ng} \mathrm{ml}^{-1}$ ), white wine and red wine with fixed amounts of IS $\left(1.82 \times 10^{-7} \mathrm{M}\right)$ under optimum UHPLC-FLD conditions are shown in Figure 1.

There are very effective HPLC-FLD methods using immunoaffinity (IAC) clean up columns available $[2,26]$. Even though IACs allow the highly selective isolation of analyte from a complex matrix, IACs have some drawbacks such as being laborious, their high cost, their limited storage time (usually 12 months), the use of large amounts of solvents and being time consuming $[28,35]$. On the other hand, it was reported that IAC columns have shown low recoveries in the analysis of wines [3638]. Therefore, the SPE clean-up procedure was preferred in this study because it is easier, cheaper and more efficient than IAC.

There have been a number of studies in the literature related to the determination of OTA in wines manufactured in many other countries using UHPLC methods. Table 2 shows a comparison of certain UHPLC methods with this method for the analysis of OTA in wines. The present study contributes to data on the occurrence of OTA in Turkey by UHPLC-FLD. The described analytical method is different in view of the use of an IS.
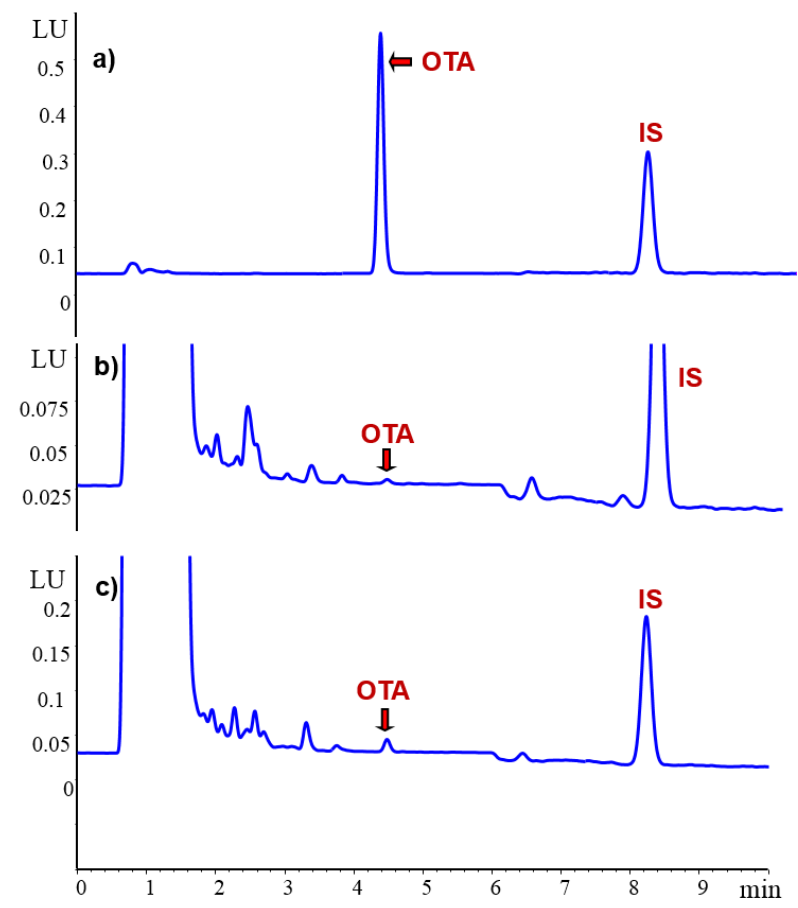

Fig. 1. Typical UHPLC-FLD chromatograms of a) OTA standard $\left.\left(45.0 \mathrm{ng} \mathrm{ml}^{-1}\right), \mathbf{b}\right)$ white wine, c) red wine with fixed amounts of IS $\left(1.82 \times 10^{-7} \mathrm{M}\right)$ in the optimum UHPLC-FLD conditions

Table 2

Comparison of analytical methods for analysis of OTA in wines by UHPLC

\begin{tabular}{|c|c|c|c|c|c|c|c|c|c|}
\hline $\begin{array}{l}\text { Method- } \\
\text { detector }\end{array}$ & $\begin{array}{c}\text { Rt (min) } \\
\text { of OTA }\end{array}$ & $\begin{array}{l}\text { Internal } \\
\text { standard } \\
\text { (IS) }\end{array}$ & Clean-up & Mobile phase & Column & $\begin{array}{c}\text { LOD } \\
\left(\mathrm{ng} \mathrm{ml}^{-1}\right)\end{array}$ & $\begin{array}{c}\text { LOQ } \\
\left(\mathrm{ng} \mathrm{ml}^{-1}\right)\end{array}$ & $\begin{array}{c}\text { Wine } \\
\text { origin }\end{array}$ & Ref. \\
\hline $\begin{array}{l}\text { UPLC- } \\
\text { FLD }\end{array}$ & NA & NA & IAC & $\begin{array}{l}\text { Water: } \\
\text { acetonitrile: acetic acid } \\
(49: 49: 2, \mathrm{v} / \mathrm{v} / \mathrm{v}) \\
\text { isocratic elution }\end{array}$ & $\begin{array}{l}\text { Waters BEH } \\
\mathrm{C} 18 \\
(2.1 \mathrm{~mm} \times 50 \\
\mathrm{mm} \times 1.7 \mu \mathrm{m})\end{array}$ & 0.01 & 0.04 & $\begin{array}{l}\text { Southern } \\
\text { Italy (or- } \\
\text { ganic } \\
\text { farming) }\end{array}$ & [26] \\
\hline $\begin{array}{l}\text { UHPLC- } \\
\text { MS }\end{array}$ & 1.59 & NA & SPE & $\begin{array}{l}\text { Solvent A: } 0.1 \% \text { formic } \\
\text { acid in water } \\
\text { Solvent B: } 0.1 \% \text { formic } \\
\text { acid in methanol } \\
\text { Gradient elution }\end{array}$ & $\begin{array}{l}\text { BEH Shield } \\
\text { RPC18 } \\
(2.1 \mathrm{~mm} \times 100 \\
\mathrm{mm} \times 1.7 \mu \mathrm{m})\end{array}$ & 0.54 & 1.81 & $\begin{array}{l}\text { France, } \\
\text { Italy, } \\
\text { Australia, } \\
\text { Chile }\end{array}$ & [27] \\
\hline $\begin{array}{l}\text { UHPLC- } \\
\text { FLD }\end{array}$ & 4.00 & NA & $\begin{array}{c}\text { On-line } \\
\text { SPE }\end{array}$ & $\begin{array}{l}\text { Solvent A: } \\
80 \% \text { Acetonitrile } \\
\text { Solvent B: } \\
1 \% \text { formic acid in water } \\
\text { (pH 2.15) } \\
\text { Gradient elution }\end{array}$ & $\begin{array}{l}\text { Kinetex XB-C18 } \\
100 \mathrm{~A}^{\circ} \\
(3.0 \mathrm{~mm} \times 30 \\
\mathrm{mm} \times 1.7 \mu \mathrm{m})\end{array}$ & 0.15 & 0.51 & Romania & [39] \\
\hline $\begin{array}{l}\text { UHPLC- } \\
\text { FLD }\end{array}$ & 4.20 & $\begin{array}{l}\text { Naphtha- } \\
\text { lene }\end{array}$ & SPE & $\begin{array}{l}\text { Water: } \\
\text { acetonitrile: acetic acid } \\
(50: 50: 1, \mathrm{v} / \mathrm{v} / \mathrm{v}) \\
\text { isocratic elution }\end{array}$ & $\begin{array}{l}\text { C18 Zorbax } \\
\text { Eclipse Plus } \\
(3.0 \mathrm{~mm} \times 100 \\
\mathrm{mm} \times 1.8 \mu \mathrm{m})\end{array}$ & 0.01 & 0.05 & Turkey & $\begin{array}{c}\text { Present } \\
\text { study }\end{array}$ \\
\hline
\end{tabular}

NA: Not available 


\subsection{Validation of the UHPLC-FLD method}

\subsubsection{Precision}

To evaluate the precision of the method, $3.60,45.0$ and $180 \mathrm{ng} \mathrm{ml}^{-1}$ of OTA solutions were injected over three consecutive days, six times each. The data are summarized in Table 3. The relative standard deviation $\left(\mathrm{RSD}\right.$ or $\mathrm{RSD}_{\mathrm{r}}$ : withinlaboratory RSD) values were found to be less than $4 \%$. The RSD values were evaluated according to the performance criteria parameters for OTA reported in Regulation (EC) No. 401/2006 [40] and
Regulation (EC) No. 519/2014 [41] and RSD values were within acceptable limits as $\leq 20\left(\mathrm{RSD}_{\mathrm{r}} \%\right.$ for $1-10 \mu \mathrm{g} \mathrm{kg}^{-1}$ of OTA level).

\subsubsection{Linearity, limit of detection ( $L O D)$, limit of quantification (LOQ)}

The method was linear in the calibration range of $0.36-180 \mathrm{ng} \mathrm{ml}^{-1}$ for OTA with good $\mathrm{r}^{2}$ values being between 0.9982 and 0.9989 (Table 4). LOD and LOQ values were $0.015 \mathrm{ng} \mathrm{ml}^{-1}$ and $0.047 \mathrm{ng} \mathrm{ml}^{-1}$, respectively.

Table 3

Repeatability assay of OTA

\begin{tabular}{|c|c|c|c|c|}
\hline \multirow{2}{*}{$\begin{array}{l}3.60 \mathrm{ng} \mathrm{ml}^{-1} \\
\text { OTA }\end{array}$} & \multicolumn{3}{|c|}{ Intra-day results ( $n=6$ each) } & \multirow{2}{*}{$\begin{array}{l}\text { Inter-day results } \\
\quad(\mathbf{n}=18)\end{array}$} \\
\hline & First day & Second day & Third day & \\
\hline $\bar{X}$ & 0.16 & 0.16 & 0.15 & 0.16 \\
\hline $\mathrm{SD}$ & 0.0047 & 0.0018 & 0.0056 & 0.006 \\
\hline $\mathrm{RSD} \%$ & 2.83 & 1.16 & 3.60 & 3.79 \\
\hline \multirow{2}{*}{$\begin{array}{l}45.0 \mathrm{ng} \mathrm{ml}^{-1} \\
\text { OTA }\end{array}$} & \multicolumn{3}{|c|}{ Intra-day results ( $n=6$ each) } & Inter-day results \\
\hline & First day & Second day & Third day & $(\mathbf{n}=18)$ \\
\hline $\bar{X}$ & 2.31 & 2.33 & 2.35 & 2.33 \\
\hline SD & 0.0514 & 0.0427 & 0.0443 & 0.047 \\
\hline $\mathrm{RSD} \%$ & 2.22 & 1.83 & 1.88 & 2.02 \\
\hline \multirow{2}{*}{$\begin{array}{l}180 \mathrm{ng} \mathrm{ml}^{-1} \\
\text { OTA }\end{array}$} & \multicolumn{3}{|c|}{ Intra-day results ( $n=6$ each) } & Inter-day results \\
\hline & First day & Second day & Third day & $(\mathbf{n}=\mathbf{1 8})$ \\
\hline $\bar{X}$ & 10.57 & 10.39 & 10.24 & 10.40 \\
\hline SD & 0.236 & 0.246 & 0.204 & 0.257 \\
\hline $\mathrm{RSD} \%$ & 2.23 & 2.36 & 1.99 & 2.47 \\
\hline
\end{tabular}

$\bar{X}$ : mean, SD: standard deviation, RSD \%: percent of relative standard deviation

Table 4

Linearity assay in the range of $0.36-180 \mathrm{ng} \mathrm{ml}^{-1}$ of OTA

\begin{tabular}{ccccc}
\hline \hline & \multicolumn{3}{c}{ Intra-day results $(\mathbf{n}=\mathbf{6}$ each) } & \multirow{2}{*}{$\begin{array}{c}\text { Inter-day results } \\
\text { Pooled }(\mathbf{n}=\mathbf{1 8})\end{array}$} \\
\cline { 2 - 4 } & First day & Second day & Third day & $0.0583 \pm 0.0002$ \\
$\mathbf{a} \pm$ SD & $0.0598 \pm 0.0004$ & $0.0708 \pm 0.0004$ & $0.0580 \pm 0.0003$ & $-0.0978 \pm 0.0178$ \\
$\mathbf{b} \pm$ SD & $-0.1783 \pm 0.0337$ & $-0.2030 \pm 0.0347$ & $-0.0980 \pm 0.0261$ & 0.9983 \\
$\mathbf{r}^{\mathbf{2}}$ & 0.9982 & 0.9986 & 0.9989 & \\
\hline \hline
\end{tabular}

a: slope, b: intercept, $r$ : correlation coefficient

\subsubsection{Accuracy}

To test accuracy, $1.80,3.60$ and $5.40 \mathrm{ng} \mathrm{ml}^{-1}$ of OTA was added to rosé wine (Table 5). The re- covery values of OTA were found to be from $102.56 \%$ to $105.16 \%$, with RSD values below $5 \%$. 
T able 5

Recovery assay for rosé wine $(l=2 ; n=3)$

\begin{tabular}{|c|c|c|c|}
\hline $\begin{array}{c}\text { Spiked OTA } \\
\text { concentration } \\
\left(\mathrm{ng} \mathrm{ml}^{-1}\right) \\
\end{array}$ & Recovery\% & SD & RSD\% \\
\hline 1.80 & 102.56 & 4.19 & 4.08 \\
\hline 3.60 & 105.16 & 1.77 & 1.68 \\
\hline 5.40 & 104.65 & 2.94 & 2.81 \\
\hline
\end{tabular}

1: number of experiments, $\mathrm{n}$ : number of injections

Recovery $\%=\left[\left(\mathrm{C}_{\text {spiked sample }}-\mathrm{C}_{\text {unspiked sample }}\right) / \mathrm{C}_{\text {added }}\right] \times 100 \%$
These recovery percentage values were acceptable according to Regulation (EC) No. 401/2006 [40] and Regulation (EC) No. 519/2014 [41] (it is recommended that Recovery \% should be 70 to 110 for $\geq 1 \mu \mathrm{g} \mathrm{kg}^{-1}$ of OTA level).

\subsubsection{Stability}

The short-term stability, long-term stability and freeze-thaw stability were investigated; results are presented in Table 6 . The results indicate that OTA is stable under the mentioned conditions.

Table 6

Stability of OTA under various conditions $(n=3)$

\begin{tabular}{|c|c|c|c|c|c|c|c|}
\hline \multirow{2}{*}{\multicolumn{2}{|c|}{$\begin{array}{l}\text { Theoretical } \\
\text { concentration } \\
\left(\mathrm{ng} \mathrm{ml}^{-1}\right)\end{array}$}} & \multicolumn{2}{|c|}{$\begin{array}{c}\text { Short-term stability } \\
(24 \mathrm{~h}, \text { room temperature })\end{array}$} & \multicolumn{2}{|c|}{$\begin{array}{l}\text { Long-term stability } \\
\left(2 \text { weeks, }-20{ }^{\circ} \mathrm{C}\right)\end{array}$} & \multicolumn{2}{|c|}{$\begin{array}{c}\text { Freeze-thaw stability } \\
\text { (3 cycles) }\end{array}$} \\
\hline & & $\begin{array}{c}\text { Recovery (\%) } \\
(\text { mean } \pm \text { SD) }\end{array}$ & $\begin{array}{c}\text { RSD } \\
(\%)\end{array}$ & $\begin{array}{c}\text { Recovery }(\%) \\
(\text { mean } \pm \text { SD })\end{array}$ & $\begin{array}{l}\text { RSD } \\
(\%)\end{array}$ & $\begin{array}{c}\text { Recovery (\%) } \\
(\text { mean } \pm \text { SD })\end{array}$ & $\begin{array}{l}\text { RSD } \\
(\%)\end{array}$ \\
\hline \multirow{3}{*}{ OTA } & 3.6 & $104.71 \pm 0.33$ & 0.32 & $96.49 \pm 3.04$ & 3.15 & $95.89 \pm 2.61$ & 2.72 \\
\hline & 45 & $103.49 \pm 0.03$ & 0.03 & $94.20 \pm 2.51$ & 2.66 & $94.87 \pm 2.20$ & 2.32 \\
\hline & 180 & $104.80 \pm 0.08$ & 0.08 & $97.03 \pm 1.98$ & 2.04 & $94.16 \pm 0.93$ & 0.99 \\
\hline
\end{tabular}

\subsubsection{Robustness}

The results of the robustness for OTA are introduced in Table 7, and it can be stated that the proposed UHPLC-FLD method is robust with low RSD percentage and standard error of the mean (SE) $\left(S E=\frac{S D}{\sqrt{n}}\right)$ values.

Table 7

The robustness of OTA (45 $\left.\mathrm{ng} \mathrm{ml}^{-1}\right)$

\begin{tabular}{ccc}
\hline Parameter & RSD\% & SE \\
\hline Flow rate $\left(\mathbf{m l ~ m i n}^{-\mathbf{1}}\right)$ & & \\
\hline $\mathbf{0 . 4}$ & 1.84 & 0.02 \\
$\mathbf{0 . 6}$ & 0.05 & 0.001 \\
\hline Column temperature $\left({ }^{\circ} \mathbf{C}\right)$ & & \\
\hline $\mathbf{2 0}$ & 0.08 & 0.001 \\
$\mathbf{3 0}$ & 3.24 & 0.04 \\
\hline The composition & & \\
of acetonitrile \% & & \\
\hline $\mathbf{4 9}$ & 1.39 & 0.01 \\
$\mathbf{5 1}$ & 1.76 & 0.02 \\
\hline \hline
\end{tabular}

\subsection{Application of the UHPLC-FLD to Turkish wine samples}

The developed and validated UHPLC-FLD method was performed on fifteen different Turkish wine samples, including white, rosé and red wines after SPE. The OTA amounts were found to be between 2.72 and $7.40 \mu \mathrm{g} \mathrm{kg}^{-1}$ in the studied Turkish wine samples; the results are shown in Table 8. OTA was not detected in white wine samples 2 and 5 in the proposed method. In all other samples, OTA concentration exceeded the maximum level given in European Commission Regulation EC $1881 / 2006\left(2 \mu \mathrm{g} \mathrm{kg}^{-1}\right)$ [10]. Generally, red wines may contain higher amounts of OTA than rosé and white wines and it is probably due to the different winemaking process $[26,28,33]$. The current study also confirmed this finding and OTA amounts in white wines were found to be lower than those for most of the red and rosé wines. The results indicated that closer OTA amounts were detected in white wine samples 4, 6 and 7, which were produced from similar grape varieties. On the other hand, two red wine samples (sample 10 and sample 14) with the highest OTA contents were from the Eastern and Southeastern Anatolia regions. Wine samples 8 and 15, including similar OTA quantities, were produced in same area (Thrace \& Aegean); however, one was rosé wine and the other wine was red wine, and their grape varieties were different from each other, apart from Cinsault. Red wine sample 12, which has a higher OTA content than twelve of the wine samples, was produced only from the grapes of Thrace region, 
unlike the other samples. Considering the results for the rest of the studied wines, it can be said that the regions of wines were similar but they were made from different types of grapes. Therefore, their results were not directly comparable. As a result, the lower/higher occurrence of OTA in wine depends on many factors such as wine making techniques, year of production or wine region due to the climatic conditions (temperature and atmospheric relative humidity), grape cultivation, mycoflora composition and storage conditions $[26,28$, $31,33]$.

\section{Table 8}

\section{OTA levels $\left(\mu \mathrm{g} \mathrm{kg}^{-1}\right)$ in various Turkish wine samples $(n=3)$}

\begin{tabular}{cccc}
\hline \hline Wine sample & $\overline{\boldsymbol{X}}$ & SD & RSD\% \\
\hline $\mathbf{1}$ (Red) & 2.72 & 0.01 & 0.53 \\
$\mathbf{2}$ (White) & $<$ LOD & - & - \\
$\mathbf{3}$ (Red) & 4.26 & 0.02 & 0.54 \\
$\mathbf{4}$ (White) & 4.41 & 0.07 & 1.68 \\
$\mathbf{5}$ (White) & $<$ LOD & - & - \\
$\mathbf{6}$ (White) & 4.22 & 0.02 & 0.51 \\
$\mathbf{7}$ (White) & 4.40 & 0.08 & 1.92 \\
$\mathbf{8}$ (Rosé) & 4.04 & 0.05 & 1.22 \\
$\mathbf{9}$ (Red) & 4.63 & 0.03 & 0.65 \\
$\mathbf{1 0}$ (Red) & 6.68 & 0.09 & 1.39 \\
$\mathbf{1 1}$ (Red) & 5.08 & 0.02 & 0.47 \\
$\mathbf{1 2}$ (Red) & 6.41 & 0.04 & 0.62 \\
$\mathbf{1 3}$ (Red) & 4.90 & 0.05 & 1.07 \\
$\mathbf{1 4}$ (Red) & 7.40 & 0.07 & 0.94 \\
$\mathbf{1 5}$ (Red) & 4.48 & 0.04 & 0.92 \\
\hline \hline
\end{tabular}

\section{CONCLUSION}

An efficient and a sensitive UHPLC-FLD method has been developed and validated for OTA analysis in different Turkish wine samples. The proposed UHPLC-FLD method is reliable, reproducible and linear for the analysis of red, rosé and white wines. The LOD and LOQ values are quite low at $0.01 \mathrm{ng} \mathrm{ml}^{-1}$ and $0.05 \mathrm{ng} \mathrm{ml}^{-1}$, respectively. OTA amounts were found to be in the range of $2.72-7.40 \mu \mathrm{g} \mathrm{kg}^{-1}$ in the Turkish wine samples. OTA contents were found to be below LOD in two of the white wine samples. In the other wine samples, OTA was found to be above the upper permitted limit of $2.0 \mu \mathrm{g} \mathrm{kg}^{-1}$ for wines, according to the European Commission Regulation EC 1881/2006 [10]. In conclusion, it is proposed that this
UHPLC-FLD method may be successfully and sensitively apply for the determination of OTA in wines.

Acknowledgements. The author appreciates the support of the Anadolu University Scientific Research Fund (AUBAP) for the project numbered 1505F207 and Eskisehir Technical University. The author is also grateful to Edward McQuaid, an English teacher at Anadolu University, for proofreading this article.

\section{REFERENCES}

[1] M. E. Zain, Impact of mycotoxins on humans and animals, J. Saudi Chem. Soc. 15, 129-144 (2011). DOI: https://doi.org/10.1016/j.jscs.2010.06.006

[2] A. Visconti, M. Pascale, G. Centonze, Determination of ochratoxin $\mathrm{A}$ in wine by means of immunoaffinity column clean-up and high-performance liquid chromatography, J. Chromatogr. A 864, 89-101 (1999). DOI: https://doi.org/10.1016/S0021-9673(99)00996-6

[3] E. Anl1, M. Bayram; Ochratoxin A in wines, Food Rev. Int. 25, 214-232 (2009). DOI: http://dx.doi.org/10.1080/87559120902956182

[4] V. Ostrý, F. Malir, M. Dofková, J. Skarková, A. PfohlLeszkowicz, J. Ruprich, Ochratoxin A dietary exposure of ten population groups in the Czech Republic: comparison with data over the world, Toxins 7, 3608-3635 (2015). DOI: 10.3390/toxins7093608

[5] A. Khoury, A. Atoui, Ochratoxin A: General overview and actual molecular status, Toxins 2, 461-493 (2010). DOI: $10.3390 /$ toxins 2040461

[6] F. J. Cabanes, F. Accensi, M. R. Bragulat, M. L. Abarca, G. Castella, S. Minguez, A. Pons, What is the source of ochratoxin A in wine?, Int. J. Food Microbiol. 79, 213215, (2002).

DOI: https://doi.org/10.1016/S0168-1605(02)00087-9

[7] I. Var, B. Kabak, Occurrence of ochratoxin A in Turkish Wines, Microchem. J. 86(2), 241-247 (2007). DOI: $10.1016 /$ j.microc.2007.04.002

[8] FAO/WHO (Food and Agriculture Organisation/World Health Organisation), Ochratoxin A. In: Safety evaluation of certain mycotoxins in food, Prepared by the 56th Meeting of the Joint FAO/WHO Expert Committee on Food Additives (JECFA). WHO Food Additives Series 47, Geneva, Switzerland, 2001, 281-387.

[9] EC (European Community), Opinion of the Scientific Committee on Food (SCF) on Ochratoxin A, 1998.

[10] Commission Regulation (EC) 1881/2006, Setting Maximum Levels for Certain Contaminants in Foodstuffs, Off J. Eur. Union L. 364, 5-24 (2006).

[11] A. G. Frenich, R. Romero-González, M. M. AguileraLuiz, Comprehensive analysis of toxics (pesticides, veterinary drugs and mycotoxins) in food by UHPLC-MS, Trends Anal. Chem. 63, 158-169 (2014). DOI: http://dx.doi.org/10.1016/j.trac.2014.06.020

[12] I. Barna-Vetro, L. Solti, J. Teren, E. Gyongsyösi, E. Szabo, A. Wölfling, Sensitive ELISA test for determina- 
tion of ochratoxin A, J. Agric. Food Chem. 44, 40714074, (1996). DOI: 10.1021/jf960442n

[13] Z. Zheng, J. Hanneken, D. Houchins, R. S. King, P. Lee, J. L. Richard, Validation of an ELISA test kit for the detection of ochratoxin A in several food commodities by comparison with HPLC, Mycopathologia 159, 265-272 (2005). DOI: $10.1007 / \mathrm{s} 11046-004-8663-3$

[14] A. Pittet, D. Royer, Rapid, low cost thin-layer chromatographic screening method for the detection of ochratoxin A in green coffee at a control level of $10 \mu \mathrm{g} / \mathrm{kg}, J$. Agric. Food Chem. 50, 243-247 (2002). DOI: $10.1021 / \mathrm{jf} 010867 \mathrm{w}$

[15] Y. Jiao, W. Blaas, C. Rühl, R. Weber, Identification of ochratoxin A in food samples by chemical derivatization and gas chromatography-mass spectrometry, J. Chromatogr. A 595, 364-367 (1992).

DOI: $10.1016 / 0021-9673(92) 85183-\mathrm{T}$

[16] J. Olsson, T. Borjesson, T. Lundstedt, J. Schnurer, Detection and quantification of ochratoxin $\mathrm{A}$ and deoxynivalenol in barley grains by GC-MS and electronic nose, Int. J. Food Microbiol. 72, 203-214 (2002). DOI: https://doi.org/10.1016/S0168-1605(01)00685-7

[17] H. Y. Aboul-Enein, Ö. B. Kutluk, G. Altiokka, M. Tunçel, A modified HPLC method for the determination of ochratoxin A by fluorescence detection, Biomed. Chromatogr. 16, 470-474 (2002).

DOI: $10.1002 / \mathrm{bmc} .187$

[18] J. Skarkova, V. Ostry, F. Malir, T. Roubal, Determination of ochratoxin A in food by high performance liquid chromatography, Anal. Lett. 46, 1495-1504 (2013). DOI: $10.1080 / 00032719.2013 .771266$

[19] M. Ibáñez-Vea, L. A. Corcuera, R. Remiro, M. T. Murillo-Arbizu, E. González-Peñas, E. Lizarraga, Validation of a UHPLC-FLD method for the simultaneous quantification of aflatoxins, ochratoxin $\mathrm{A}$ and zearalenone in barley, Food Chem. 127, 351-358 (2011).

DOI: $10.1016 /$ j.foodchem.2010.12.157

[20] M. Mincea, C. Ionascu, K. Kis, V. Ostafe, Detection of ochratoxin A in instant coffee by UPLC-MS/MS, Studia UBB Chemia 2, 167-175 (2016).

[21] M. W. Dong, K. Zhang, Ultra-High-Pressure liquid chromatography (UHPLC) in method development, Trends Analyt. Chem. 63, 21-30 (2014). DOI: 10.1016/j.trac.2014.06.019

[22] S. Fekete, J. Schappler, J.-L. Veuthey, D. Guillarme, Current and future trends in UHPLC, Trends Analyt. Chem. 63, 2-13 (2014). DOI: $10.1016 /$ j.trac.2014.08.007

[23] I. Klimczak, A. Gliszczynska-Swigło, Comparison of UPLC and HPLC methods for determination of vitamin C, Food Chem. 175, 100-105 (2015). DOI: 10.1016/j.foodchem.2014.11.104

[24] R. Mikulíková, S. Beláková, K. Benešová, Z. Svoboda, Study of ochratoxin A content in South Moravian and foreign wines by the UPLC method with fluorescence detection, Food Chem. 133, 55-59 (2012). DOI: $10.1016 /$ j.foodchem.2011.12.061

[25] C. L. De Jesus, A. Bartley, A. Z. Welch, J. P. Berry, High incidence and levels of ochratoxin $\mathrm{A}$ in wines sourced from the United States, Toxins 10, 1-12 (2018). DOI: $10.3390 /$ toxins 10010001

[26] F. Gentile, G. L. La Torre, A. G. Potortì, M. Saitta, M. Alfa, G. Dugo, Organic wine safety: UPLC-FLD determination of ochratoxin A in Southern Italy wines from organic farming and winemaking, Food Control 59, 20 26 (2016). DOI: 10.1016/j.foodcont.2015.05.006

[27] J. Li, X. Liu, S. Han, J. Li, Q. Xu, H. Xu, Y. Wang, F. Liu, Z. Zhang, Analysis of ochratoxin A in wine by High-Resolution UHPLC-MS, Food Anal. Methods 5, 1506-1513 (2012). DOI: https://doi.org/10.1007/s12161-012-9403-9

[28] A. Leitner, P. Zöllner, A. Paolillo, J. Stroka, A. Papadopoulou-Bouraoui, S. Jaborek, E. Anklam, W. Lindner, Comparison of methods for the determination of ochratoxin A in wine, Anal. Chim. Acta 453, 33-41 (2002). DOI: $10.1016 / \mathrm{S} 0003-2670(01) 01483-0$

[29] E. Anlı, B. Çabuk, N. Vural, E. Başpınar, Ochratoxin A in Turkish wines, J. Food Biochem. 29, 611-623 (2005). DOI: https://doi.org/10.1111/j.1745-4514.2005.00043.x

[30] G. Altiokka, N. O. Can, Z. Atkoşar, H. Y. Aboul-Enein, Determination of ochratoxin A in Turkish wines, JFDA 17(6), 467-473 (2009).

[31] M. J. Hernandez, M. V. Garcia-Moreno, E. Duran, D. Guillen, C. G. Barroso, Validation of two analytical methods for the determination of ochratoxin A by reversed-phased High-Performance Liquid Chromatography coupled to fluorescence detection in musts and sweet wines from Andalusia, Anal. Chim. Acta 566, 117-121 (2006). DOI: 10.1016/j.aca.2006.02.002

[32] The International Conference on Harmonization (ICH), Validation of Analytical Procedures: Methodology, Topic Q2B, CPMP/ICH/281/95, 1996.

[33] N. Belli, S. Marin, V. Sanchis, A. J. Ramos, Review: Ochratoxin A (OTA) in wines, musts and grape juices: Occurrence, regulations and methods of analysis, Food Sci. Tech. Int. 8(6), 325-335 (2002).

DOI: https://doi.org/10.1106/108201302031863

[34] A.-M. Turcotte, P. M. Scott, Ochratoxin A in cocoa and chocolate sampled in Canada, Food Addit. Contam. 28, 762-766 (2011). DOI: 10.1080/19440049.2010.508796

[35] L. Campone, A. L. Piccinelli, L. Rastrelli, Dispersive liquid-liquid microextraction combined with highperformance liquid chromatography-tandem mass spectrometry for the identification and the accurate quantification by isotope dilution assay of Ochratoxin A in wine samples, Anal. Bioanal. Chem. 399, 1279-1286 (2011). DOI: https://doi.org/10.1007/s00216-010-4347-7

[36] D. Jornet, O. Busto, J. Guasch, Solid-phase extraction applied to the determination of ochratoxin $\mathrm{A}$ in wines by reversed-phase high-performance liquid chromatography, J. Chromatogr. A 882, 29-35 (2000). DOI: https://doi.org/10.1016/S0021-9673(00)00237-5

[37] J. M. Sáez, Á. Medina, J. V. Gimeno-Adelantado, R. Mateo, M. Jiménez, Comparison of different sample treatments for the analysis of ochratoxin A in must, wine and beer by liquid chromatography, J. Chromatogr. A 1029, 125-133 (2004). DOI: https://doi.org/10.1016/j.chroma.2003.12.021 
[38] A. Prelle, D. Spadaro, A. Denca, A. Garibaldi, M. L. Gullino, Comparison of clean-up methods for ochratoxin A on wine, beer, roasted coffee and chili commercialized in Italy, Toxins 5, 1827-1844 (2013).

DOI: https://doi.org/10.3390/toxins5101827

[39] A.-M. Nistor, S.-D. Cotan, C.-B. Nechita, A. Tartian, M. Niculaua, V. V. Cotea, Rapid assessment of mycotoxins in wine by on-line SPE-UHPLC-FLD, BIO Web of Conferences 9, 6 (2017)

DOI: https://doi.org/10.1051/bioconf/20170902022
[40] Commission Regulation (EC) No 401/2006 of 23 February 2006 Laying Down the Methods of Sampling and Analysis for the Official Control of the Levels of Mycotoxins in Foodstuffs, Off. J. Eur. Union L70, 12-34 (2006).

[41] Commission Regulation (EC) No 519/2014 of 16 May 2014 amending Regulation (EC) No 401/2006 As Regards Methods of Sampling of Large Lots, Spices and Food Supplements, Performance Criteria for T-2, HT-2 Toxin and Citrinin and Screening Methods of Analysis. Off. J. Eur. Union L147, 29-43 (2014). 